\title{
Justiça Administrativa
}

Maurício DE Lima E Silva

O PRIMADO DA LEI

\begin{abstract}
A administração, no Estado moderno, não dispõe de um poder arbitrário, em sentido absoluto. A discrição de seus atos está limitada pela lei. Corno - particular, deve observar as regras do direito e, se as viola, sujeita-se às sançōes 'egais, aplicadas através da justiça. E' essa supremacia da lei que caracteriza o Estado legal, o Estado de Direito. Sabemos que a cada direito se contrapõe um dever. A lei existe para assegurar a livre fruição dos direitos, impondo sua tolerância por parte do titulares do dever jurídico, seja ëste o particular ou a administração. Nêste último caso, a liberdade individual, sob a tutela da lei e a ação corretora da justiça, é preservada contra as atuações abusivas do poder público.
\end{abstract}

\section{REGIMES JURISDICIONAIS}

Entretanto, não é uniforme a maneira pela qual o Estado moderno se submete ao Direito e à Justiça. Difere fundamentalmente em dois grandes tipos: ora temos a administração subalterna ao mesmo direito e à mesma justiça que o particular; ora ela se subordina a um direito especial administrado por um tribunal também especial. O primeiro sistema é denominado sistema de unidade jurisdicional; o último, sistema de dualidade jurisdicional. Aquêle tem por paradigma a justiça dos países anglo-saxões e é adotado no Brasil; êste tem por modêlo a justiça francesa e é seguido por quase todos os Estados da Europa Continental.

Estes dois grandes tipos são suscetíveis de se combinarem sob diversas formas, ao influxo, na maioria das vêzes, das contingências da dinâmica histórica de cada país. Mas é fora de dúvida que a jurisdição dual tende. mais e mais, a prevalecer dentre os diferentes sistemas existentes. Isso porque se vai configurando sua excelência à medida que se precisa a posıção sui generis do direito administrativo. O sistema da unidade jurisdicional restringe ao poder judiciário a competência para apreciar em definitivo os atos em que o Estado fôr diretamente interessado. Os anglo-saxões. motivados por um excessivo culto do liberalismo, repelem a idéia da dualidade de jurisdição: parece-lhes essencial à configuração do regime liberal que a administração pública esteja submetida ao direito nas mesmas condiçöes em que está o simples particular. A fórmula dùal parece-lhes como que uma quebra do princípio liberal. Seria a expressão de um sistema de privilégio em favor da administração. 
Nada mais ilusório. A imputação caberia sòmente nos casos em que a própria autoridade administrativa julgasse em definitivo os atos por ela praticados. Não é o que acontece, porém, na hipótese da existência de uma justiça administrativa. Esta pressupõe uma completa autonomia de ação no julgamento dos conflitos de que participa o Estado. Embora integrada na estrutura da administração pública, a esta se sobrepõe em virtude da pró. pria natureza e das condições de exercício de suas funções jurisdicionais.

O luberalismo do sistema jurisdicional francês é um argumento de pêso em face dos temores anglo-saxões. O observador imparcial pode verificar como os tribunais administrativos francêses, tendo à frente o Conselho de Estado, vêem de há muito, firmando seu papel de defensor dos direitos dos administrados, no que diz respeito, principalmente, à legalidade e à responsabilidade dos atos da administração. A especificidade do direito administrátivo, bem como sua fundamentação teleológica, são outros elementos poderosos em favor da dualidade jurisdicional, como veremos em seguida.

\section{AUTONOMIA DO DIREITO ADMINISTRATIVO}

O Direito Administrativo manifesta-se em todos os seus aspectos como um direito especial regido por normas fundamentalmente diversas das do direito comum. Podemos observar esta autonomia quando consideramos, por exemplo: as relações jurídicas entre o funcionário e o Estado, a condição jurídica do domínio público, a feição especialíssima dos contratos de Direito Público, a responsabilidade civil do Estado, etc. Essa autonomia manifesta-se: tanto mais nítida, se levarmos em conta que, ela não se refere à nuança ou a regras acessórias mas, sim, que se caracteriza através de aspectos diferenciais, fundamentais como, por exemplo, a inalienabilidade do domínio público ou a feição estatutária da situação jurídica do funcionário.

Não se pode dizer que essa autonomia constitua mera forma de racionalização disfarçando sempre o interêsse da administração. Longe disso: a teoria do risco, no campo da responsabilidade civil ou a teoria da imprevisão, em matéria contratual, são exemplos eloqüentes de teorias favoráveis ao particular nas suas relações de direito administrativo.

Por outro lado, o caráter particularista do direito administrativo se ma. nifesta sobretudo através das chamadas prerrogativas de direito público, que nāo encontram analogia no campo do direito comum. Elas têm por base o poder de coagir através do ato unilateral; permitem à administração cons. tranger o particular a um fazer, a um não fazer ou a um tolerar que se faça, e assim contrastam fortemente com os princípios do direito privado, impregnados pela concepção da autonomia da vontade. Assim acontece quando a administração impõe ao administrado regras gerais (leis, regulamentos, etc) ou particulares (injunções). Assim acontece quando o particular é coagido ao cumprimento de prestações em dinheiro (taxação) ou em bens imóveis e móveis (desapropriações, requisições).

As prerrogativas de direito público constituem, portanto, as manifestações mais espetaculares da especificidade do direito público.

Ora, essa especificidade não se justifica como um instrumento de dominação do particular pelo Estado. Muito ao contrário, ela decorre essencialmente da noção de serviço público. A noção de soberania. 
Em pleno século XVIII e mesmo em boa parte do século XIX, esteve muito em voga a idéia da soberania. O Estado era compreendido como uma pessoa jurídica dotada de qualidade especial - a soberania - que o colocava em uma posição de prevalência, em suas relações com o particular. O direito civil concebıdo na base da igualdade das vantagens não poderia ser válido para a tutela das relações entre êsse Estado soberano e os indivíduos. Donde a necessidade da existência de um direito especial para essas relações; donde a justificação do direito administrativo.

\section{ATOS DE IMPÉRIO, ATOS DE GESTÃO}

A noção de soberania foi posteriormente corrigida pela distinção entre atos de império e atos de gestão. O Estado, admitia-se, nem sempre agia na qualidade de entidade soberana. Isso só se dava quando êle atuava autoritàriamente sob a forma de ordens, interdições, regulamentações, etc. Nêsses casos, os atos praticados pelo Estado eram atos de império. Ao contrário, se êle não fizesse uso de seu poder impositivo, mas se comportasse como simples particular, ao tratar de igual para igual em suas relações com o administrado, estariamos em face de atos de gestão.

A distinção era importante porque limitava o campo de aplicação do direito administrativo. Sòmente os atos de império estariam sob a tutela do direito administrativo: para a atividade de gestão prevalecia o direito comum.

\section{A NOÇÃO DO SERVIÇO PÚBLICO}

Hoje não há que falar de poder público ou soberania. A distinção entre atos de império e atos de gestão apresenta aspectos fronteiriços, "zonas cirzentas" que engendram situações problemáticas ao pretender-se dicotonizá-las para o preto ou para o branco. Duguir e outros autôres, ao estabelecerem crítica enérgica à noção de soberania, lançaram a concepção do serviço público que domina modernamente como fundamento e como campo de apli. cação do direito administrativo.

Por serviço público entende-se todo empreendimento da entidade pública, visando à satisfação de uma necessidade de interêsse geral, v.g., a ordem publica, a defesa nacional, os serviços de telecomunicações, etc.

Esta concepção liga-se essencialmente à idéia do interêsse geral: não é cutro o fim a que visa o serviço público. O Estado, ao constatar, que uma cleterminada necessidade de ordem geral não vem sendo satisfeita ou o vem sendo de modo precário através da iniciativa particular, chama a si o encargo e erige em serviço público as atividades destinadas à sua satisfação.

Ora, ao servir de fundamento à idéia de direito administrativo, o serviço publicc serve ao mesmo tempo de base para o conceito de jurisdição administrátıva. Esta tem precisamente razão de ser no fato de existir um direito especial a aplicar.

Também o campo de aplicação da justiça adminiştrativa está limitado pela noção de serviço público. Sòmente quando existe serviço público é que se aplica o direito administrativo e, por conseguinte, só nêste caso se configura a competência da justiça administrativa. 


\section{JURISDIÇÃO ADMINISTRATIVA}

Por jurısdição administrativa entende-se a esfera de tribunais especiais distinta da esfera de tribunais jurisdicionais e destinada a apreciar os litígios suscitados pela atividade administrativa.

Vımos que a justificação da justiça administrativa está na necessidade: que se tem, de aplicar um direito especial.

Ora, êsse aspecto escapa totalmente às razões de ordem histórica que motivaram o surgimento da justiça administrativa.

Razōes políticas e constitucionais, e não, argumentos de técnica jurídica, provocaram o processo de emancipação da jurisdição administrativa francesa, o protótipo da dualidade de jurisdição. Tais razões se relacionam intimamente com o princípio da separação dos poderes.

\section{SEPARAÇÃO DE PODERES}

Não há grande evidência no esclarecimento acima, mas uma vez que as países anglo-saxões assistiram ao nascimento do princípio da separação cios poderes (Locke, Montesquieu e os constitucionalistas norte-americanos) e - paradoxal! - precisamente nêle fundamentam a existência da unidade jurisdicional. O exercício da função judicial pela administração parece-lhes a quebra do princípio pela usurpação de atribuições que, no seu entendimento, são da competência exclusiva do poder judiciário.

A experiência constitucional vem, dia a dia, pondo à mostra os aspectos negativos de uma tal hermética compreensão. Exemplo expressivo está no abandono por que vem passando a idéia da delegação de poderes.

0 entendimento francês, pôsto que antagônico, mostra-se mais consentảneo com o aspecto unitário do Estado moderno. Há que se compreender os poderes políticos como sub-unidades de um poder supremo perfeitamente entrosado no sentido de colaborarem adequadamente, cada qual em seu campo específico, para a consecução dos fins do Estado. Não é possivel o estabelecimento das relações entre os três poderes em base de concorrência ou competição. Há de predominar a cooperação, a colaboração. Nêste sentido é o que os franceses entendem como contrário ao princípio de separação dos poderes, a apreciação do contencioso administrativo pelo poder judiciário, porque, desta maneira, êste teria uma certa ingerência no campo da administraçāo.

Esta concepção tem um profundo lastro histórico: ela reporta aos dias tormentosos da Revolução Francesa, em que predominava uma profunda aversão popular a uma jüstiça controlada pelo absolutismo do Príncipe.

Este espírito anti-judiciário veio engendrar uma separação absoluta entre a administração e o sistema judicial, e sua racionalização encontrou tundamento no emergente princípio de separação dos poderes, transplantado da concepção filosófico-constitucional dos anglo-sexões.

Assim, ao passo que, na concepção anglo-saxônica, a separação entre o contencioso administrativo e a administração ativa é considerada como a regra necessária, decorrente do princípio da separação dos poderes, na concepçầo trancêsa, a regra necessàriamente decorrente é a da separação entre 
o contencioso administrativo e o poder jurisdicional. Esta concepção encontrou expressảo primeira no texto célebre de 16-24 de agôsto de 1790 :

"Les fonctions judiciaires sont et demeureront toujuors separées des fonctions administratives. Les Júges ne pourront, à peine de fortaiture: troubler de quelquer manière que ce sont les operations des corps administratifs, ni citer devant eux les administrateurs pour raison leurs fonctions".

Nêstes têrmos, a solução adotada primitivamente foi paradoxal. O julgamento do contencioso administrativo ficou a cargo das próprias autoridades administrativas: o rei, os ministros, e os administradores de departamentos. Este sistema, chamado de sistema do administrador-juiz, prevaleceu por todo o período revolucionário, mas não tardou a parecer chocante em face das tendências liberais. Urgiu que se separassem, administração e jurisdição. E' o mesmo princípio da separação dos poderes que vai servir de base dogmática para esta idéia: interpretado sob o seu aspecto da especialização, adjudicou-se à idéia inicial da separação entre as autoridades administrativas e as autoridades judiciárias, a exigência da separação entre a administração ativa e a administração contenciosa. Portanto, o que se estabeleceu foi o corpo de tribunais separados, não só do poder judiciário, como também do poder administrativo. Eis aí a explicação histórica da jurisdição admınistrativa francêsa. Do administrador-juiz até a justiça homologável predominou a preocupação anti-jurisdicional. Só com a justiça delegada vai-se estabelecer nitidamente a jurisdição administrativa francêsa. Aí está também a razao por que a solução francêsa não se efetivou senão através do progressivo evolver dos fatos e das instituições. Hoje seu fundamento lógico está na especificidade do direito administrativo. Nem por isso se estagonizam antes completam-se as duas concepções: uma, em têrmos da história, outra, em premissas de lógica. Aqui Platão e Aristóteles se encontram e reconcilram-se.

A eviđência da justiça administrativa, mais eficiente e mais adequada, encontramo-la quer perquirindo o mundo das idéias, quer buscando a realidade dos fatos. Deduzindo do ideal ou induzindo do real.

\section{B I B L I O G R F I A}

ARAGĀo, J. G. - La Jurisdiction Administrative au Brèsil, tese (Paris, 1954).

Cavalcantr, Themistocles Brandão - Curso de Direito Administrativo, Ca. XIV, "Da Justiça na Administração", Liv. Freitas Bastos S.A. (Rio, 1954) págs. 479 a 496.

Cavalcantr, Themistocles Brandão - Tratado de Direito Administrativo, vol. VI, Tí.tulo II, "Da Justiça na Administração", Livraria Freitas Bastos S. A. (Rio, 1951) págs. 127 a 195 .

FrNer, Herman - Theory and Pratice of Modern Government, Revised, Henry Haltand Company (New York), 1950) págs. 918 a 932.

GAzIer, François - A Justiça Administrativa na França, Caderno de Admininstração Pública, n. 15 - Fundação Getúlio Vargas (Rio, 1955), passim.

Laubadère, André de - Manual de Droit Administrative, Troisième Edition, Librairie Générale de Droit et de Jurisprudence (Paris, 1951) págs. 38 a 69.

Robson, W. A. - Justice and Administrative Law, Third Ed., Stevens \& Sons Ltd. (London, 1951) págs. 26 a 39,540 a 545,546 a 641 . 